\title{
Pathways to Asian Civilizations: Tracing the Origins and Spread of Rice and Rice Cultures
}

\author{
Dorian Q. Fuller
}

Received: 29 October 2011 / Accepted: 8 December 2011 /Published online: 4 January 2012

(C) Springer Science+Business Media, LLC 2011

\begin{abstract}
Modern genetics, ecology and archaeology are combined to reconstruct the domestication and diversification of rice. Early rice cultivation followed two pathways towards domestication in India and China, with selection for domestication traits in early Yangtze japonica and a non-domestication feedback system inferred for 'proto-indica'. The protracted domestication process finished around 6,500-6,000 years ago in China and about two millennia later in India, when hybridization with Chinese rice took place. Subsequently farming populations grew and expanded by migration and incorporation of pre-existing populations. These expansions can be linked to hypothetical language family dispersal models, including dispersal from China southwards by the Sino-Tibetan and Austronesian groups. In South Asia much dispersal of rice took place after Indo-Aryan and Dravidian speakers adopted rice from speakers of lost languages of northern India.
\end{abstract}

Keywords Domestication · Origins of Agriculture . Archaeology · Historical Linguistics · Genetics . Archaeobotany

\section{Introduction}

Rice as food and crop is central to the identities of many Asian societies, indeed most mainstream state cultures in East, Southeast and South Asia, from the Japanese to Sichuanese, to the Thai or Sri Lankan Sinhala see rice as a core part of their cultural tradition. Rice is central to the civilizations of monsoon Asia in two senses. For many Anglo-American archaeologists and anthropologists, "civilization" refers to

\section{Q. Fuller $(\bowtie)$}

Institute of Archaeology, University College London,

31-34 Gordon Square,

London WC1H OPY, UK

e-mail: d.fuller@ucl.ac.uk hierarchical, complex societies of states (e.g. Trigger 2003), and rice has been part of agricultural production of most of these from the Ganges to the Mekong to China's central plains (although one can argue that millets were more central to the earliest Chinese (Xia-Shang-Zhou) state(s)). Other anthropologists, such as those from the French Maussian tradition, use civilization in the sense of a larger regional shared core of cultural ideas, within which many states and smaller societies may be grouped (e.g. Durkheim and Mauss 1913; Swedberg 2010; also, Rowlands 2003). As succinctly summarized by Wengrow (2010: xviii) civilization "should refer to historical outcomes of exchanges and borrowings between societies rather than to processes or attributes that set one society apart from another." I would suggest the study of civilization must pay attention to both the borrowings that link large geographical and population areas and ways in which those borrowings are reshaped to be adapted to local cultural styles and differences within the area. A later historical example is provided by Buddhism which spread widely through monsoon Asia but took on very different regional expressions in China, Japan, Thailand or Sri Lanka. The sharing of rice agriculture is an earlier example, which shows as much regional variation in cultivation styles and preferences as it shows similarities.

Rice is clearly central to wider East Asian, Southeast Asian and South Asian civilization areas in terms of economy and landscape (Gorou 1984; Bray 1994). Indeed some scholars have pointed to a great and fundamental contrast between the civilization(s) of rice and Mediterranean bread cultures (e.g. Watsuji 1961; Hardricourt 1962; Hosoya et al. 2010). Fuller and Rowlands $(2009,2011)$ highlight the linked tradition of cooking (boiling and steaming), food textural preference (sticky, as with glutinous rice), and feasting and ritual focused on keeping ancestors close. Whichever definition of civilization is preferred, it is clear that the history of Asian societies, their human populations and the evolutionary history of rice as a crop are inseparable. The 
importance of rice agriculture as a motor for demographic growth, population expansion and origins of sedentary village life has been stressed by many archaeologists and forms a key component in the farming/language dispersal hypothesis (e.g. Higham 2003; Bellwood 1996, 1997, 2011; Blust 1996; Sagart 2003) This paper assesses our current state of knowledge about the beginnings of rice cultivation and the spread of rice inferred from archaeobotanical evidence, its congruence with genetic inferences and how this might have been linked to major cultural traditions represented by language families.

\section{The ecologies of rice's wild relatives: two pathways to cultivation}

Rice can be inferred to have entered cultivation on two pathways from wild ecology and human use. The wild progenitors of Asian rice are well-known to include Oryza rufipogon sensu stricto and Oryza nivara, which are native to South and Southeast Asia, extending northwards into Southern China. Modern distribution maps are potentially misleading for a couple of important reasons: first and foremost, there has been climatic change such that areas of suitable tropical and subtropical climate with suitable wetland areas will have shifted dramatically over the past 20,000 years. Such environments would have necessarily peaked in the earlier Holocene when summer insolation in the northern hemisphere was significantly higher (it fell gradually from about 7000 BP to present, Berger 1978) and during the first half of the Holocene (until about 5,000 or 6,000 years ago) monsoon rainfall was much higher (e.g. Burns 2011; see also, Fuller and Qin 2010). The postPleistocene expansion of wild rice, from southern tropical refugia of the glacial period northwards to eastern China and the Yangtze basin (Fig. 1), would have entailed at least one if not several population bottlenecks in $O$. rufipogon. Another reason modern maps are potentially misleading is that the potential habitats for wild rice have been removed through human action over the past few thousand years, especially through the reclamation of wetlands for agriculture. As a result many wild rice populations have presumably been extirpated. Evidence for this comes from Chinese texts from the Song dynasty (just over 1,000 years ago, under essentially modern climatic conditions) which indicate the former presence of wild rice populations in eastern China in the Lower Yangtze and northwards to Shandong (Ho 1977; You 1987).

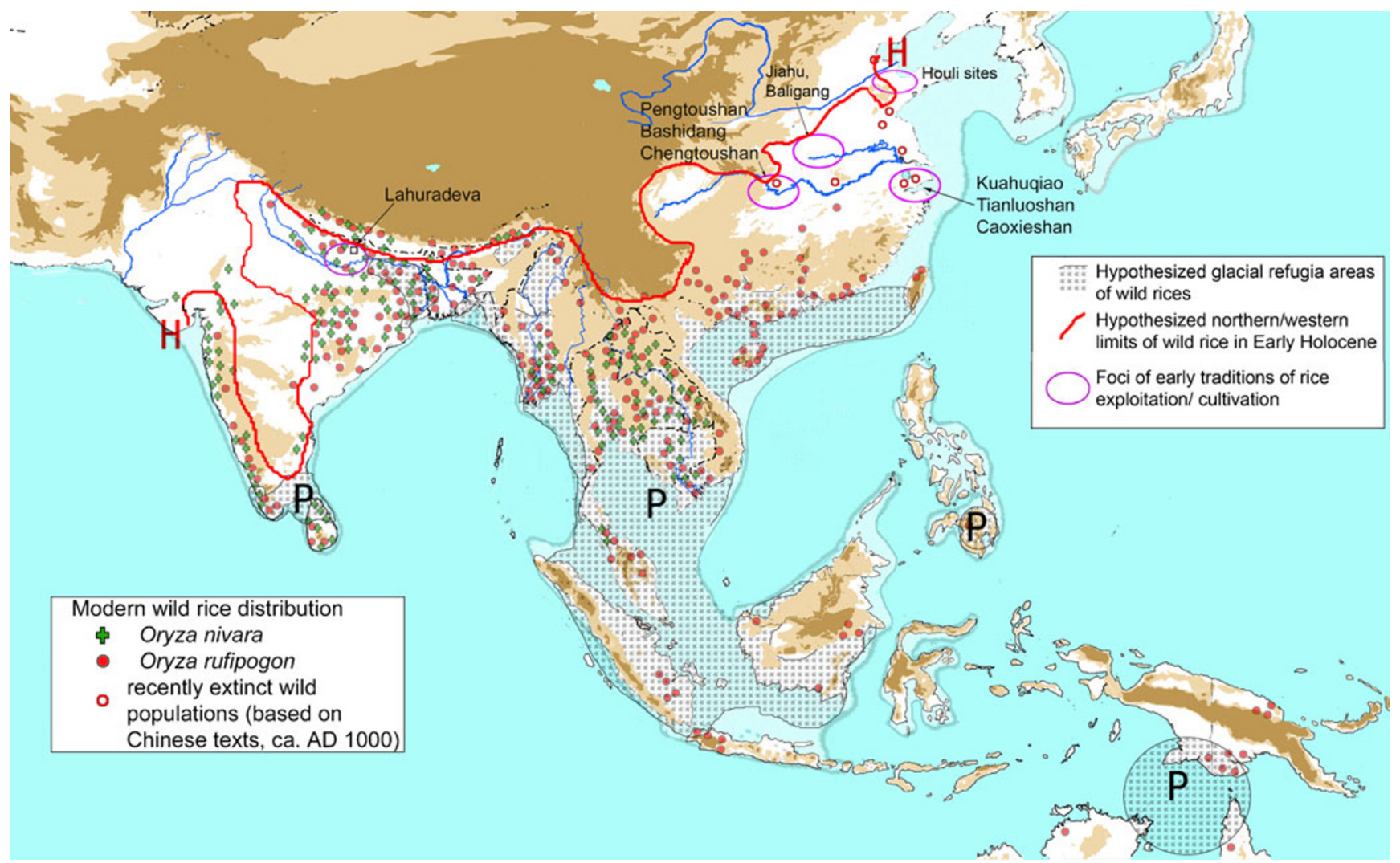

Fig. 1 Map of Last Glacial (20,000 BP) refugial wild rice zones $(P)$ versus Early Holocene $(9,000 \mathrm{BP})$ expansion $(H)$ of wild rice in comparison to recent populations indicated by crosses and circles (after
Fuller et al. 2010a). Early foci of archaeological evidence relating to early cultivation are indicated. 
There has long been a case to be made for the separate origins of domesticated indica and japonica rice subspecies, from various modern genetic markers, from old-fashioned crossing to re-sequenced genomes (e.g. Garris et al. 2005; Londo et al. 2006; Kawakami et al. 2007; He et al. 2011). Recent versions of this scenario highlight the necessity of hybridization between a fully domesticated japonica and semi-domesticated or wild proto-indica (Figs. 2 and 3), whereby japonica became the donor of many domestication syndrome genes in indica (Sang and Ge 2007; Sweeney and McCouch 2007; Fuller et al. 2010a). It is worth noting that there are still emerging complications in the story of early domestication genes, since experiments by Ishikawa et al. (2010) indicate that plants homozygous for the sh4 nonshattering mutation still show wild-type shattering in the context of mainly wild-type genetic background, i.e. there are other interacting alleles yet to be identified. Because of incomplete compatibility between japonica and indica rices, first-generation hybrids would have had low fertility requiring back-crossing to one or the other parent (Sato 1996); in the context of India, this is likely to have been the widespread, and climatically adapted, proto-indica. A model of this process is provided by the development of Oryza glaberimma $\times$ Oryza sativa hybrids in West Africa, which has been well described ethnographically and genetically (Nuijten et al. 2009). There does persist some debate on this issue, but even those who favour a single origin (e.g. Vaughan et al. 2008; Molina et al. 2011a) allow for significant introgression with wild rices elsewhere (in India and perhaps Southeast Asia).

The differing ecologies of the rufipogon perennial and nivara annual ecotypes of the wild rice imply differing modes of hunter-gatherer exploitation and the importance and intensity of early cultivation that was necessary (Fuller and Qin
2009). The perennial rufipogon would have normally been a fairly poor grain resource, with more metabolic energy invested in vegetative tissues. This necessitated human manipulation of soil and water environment to induce a drought response of higher grain productivity. Over time there would have been selection for more annuality and reduced vegetative growth (shorter and straighter growth habit), as well as increasing grain yields and grain size. Thus more intensive human efforts at managing the soil and water conditions of early cultivated rufipogon would have been repaid by increasing yields and the accumulation of domestication genes. The archaeological evidence from the Lower Yangtze supports this inferred process (Fuller and Qin 2009, 2010). By contrast, the annual $O$. nivara wild rices could have been exploited on a large scale without any serious cultivation, or selection of habit changes or domestication traits. This represents a "proto-indica" hypothesis (Fuller et al. 2010a) in which intensive exploitation of proto-indica wild types, which probably included burning off competing vegetation and some broadcast sowing, could have taken place for millennia without the evolution of domesticated rice (Fuller 2011). In other words we would expect the adaptive syndrome of annual wild rice (Grillo et al. 2009) to have been reinforced through such proto-cultivation.

\section{How independent was early rice farming in the Ganges? clarifying northwestern or northeastern inputs}

In Gangetic India, archaeological evidence has for a while been taken to indicate local independent origins of agriculture (e.g. Fuller 2002, 2006a, b, 2007; Saraswat 2005). Clear evidence for a local domestication process, however, is still missing.
Fig. 2 Hypothetical representation of the phylogenetic history within rice over time, with hybridizations, and lost lineages, and diversity not sampled in modern germplasm represented. Modified from a diagram in Gross and Olsen (2010). $X$ hybridization event. Potential lineages of the Neolithic Ganges, i.e. the 'proto-indica' encircled by green dashed line. Note that lost rice lineages are meant to be suggestive and representative, but it is not yet possible to develop detailed hypotheses.

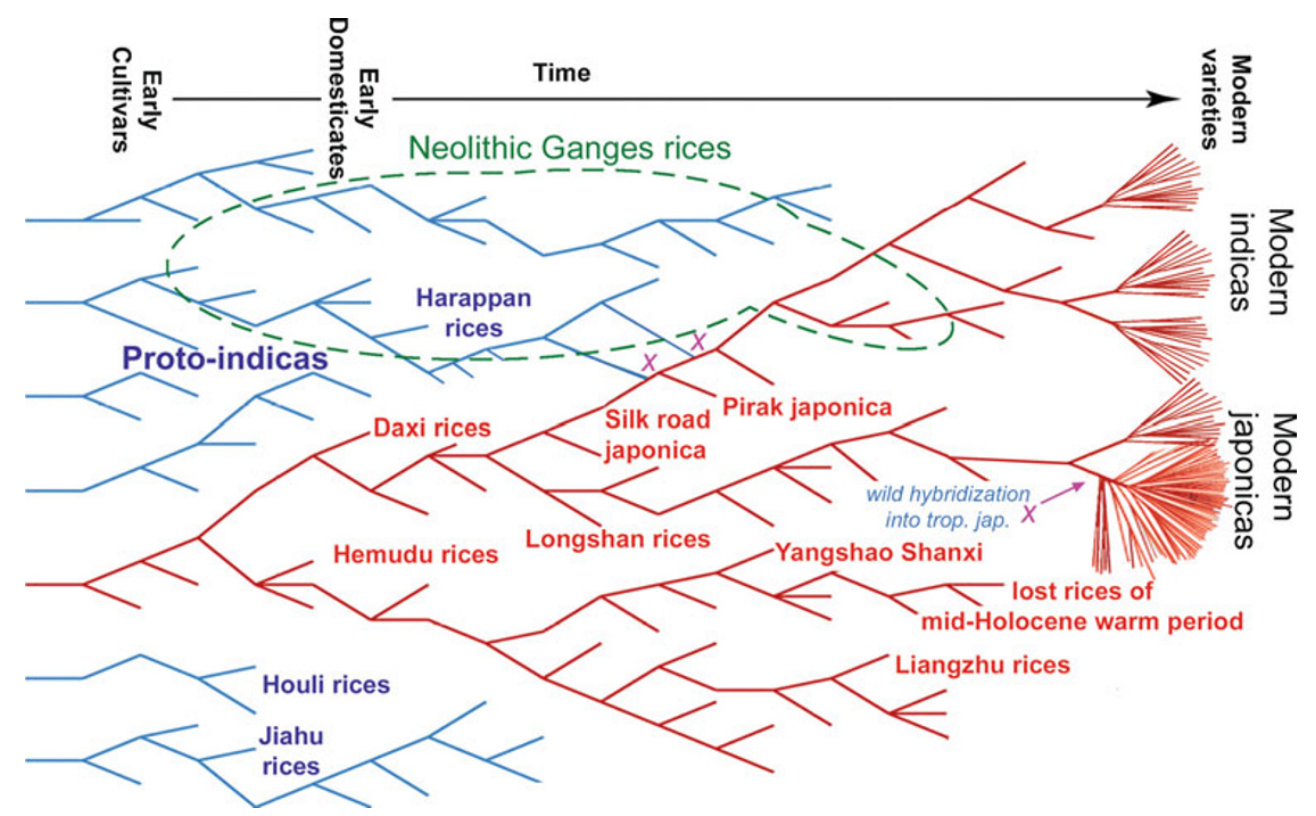


Fig. 3 Contrasting the feedback loops of the protoindica hypothesis (bottom) and the japonica domestication pathway (left). This has been added to a diagram contrasting wild versus domesticated crop processing (Fuller et al. 2010b).

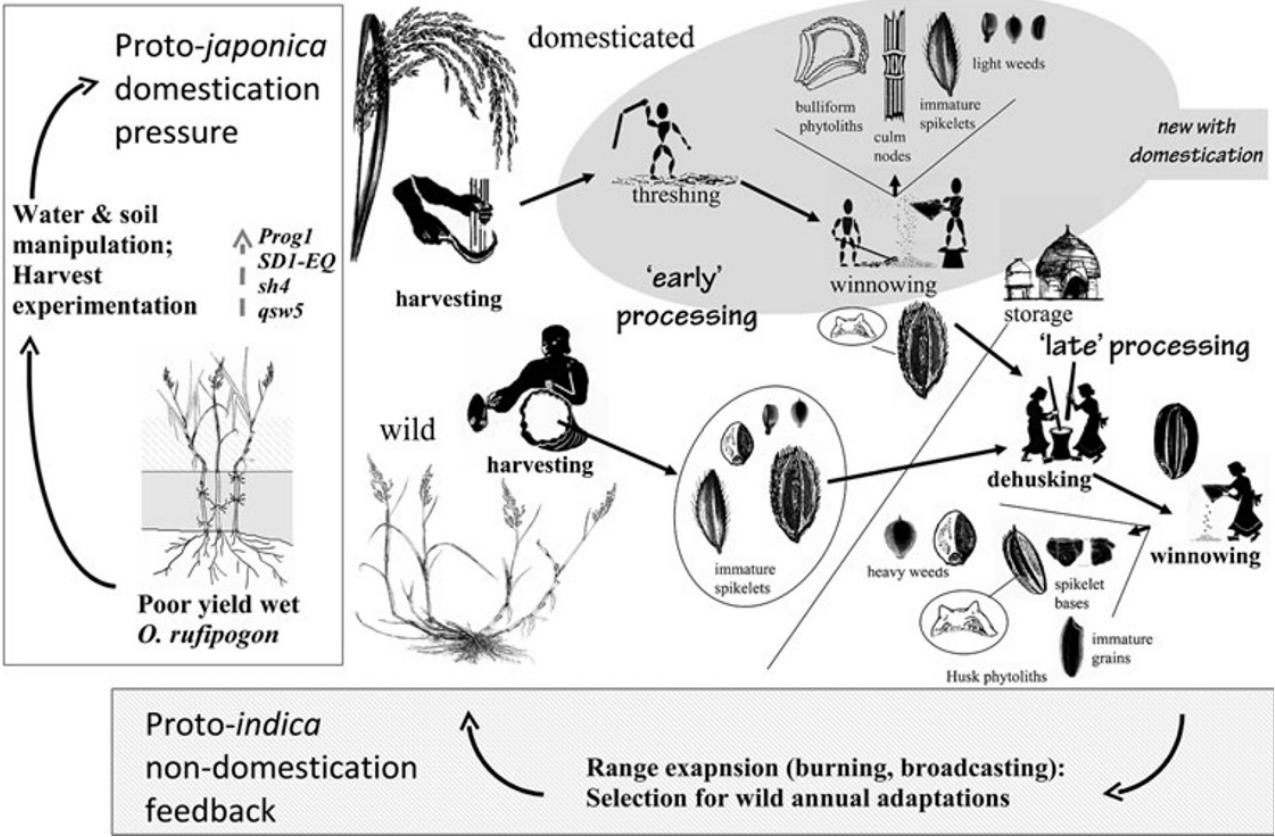

Instead, what archaeology has revealed is quite a lot about the integrated agricultural systems of the very late Neolithic, a period in which continuously occupied sedentary villages become the norm. This mostly dates from 2200 or $2000 \mathrm{BC}$ to the early centuries of the second millennium (Fuller 2006a, 2011). Earlier occupations are likely to have been more mobile, i.e. this is the problem of "silence before sedentism" which has limited pinpointing that the actual origins of cultivation in much of inner India (Fuller 2006b). Increasingly, I think this makes sense in terms of early agricultural settlements in much of India being frequently moved due to practices of shifting cultivation, leaving a poor and ephemeral archaeological record and precluding much direct archaeobotanical evidence (Kingwell-Banham and Fuller 2011). Nevertheless the few early sedentary sites with good evidence, such as Senuwar (from $2500 \mathrm{BC}$ ), suggest that there was a reliance on rice, probably cultivation, before crops from elsewhere were introduced (Saraswat 2004; discussions in Fuller 2006a, b, 2011).

The introduction of domesticates from the west (the Indus region), may have started as early as 2400-2200 $\mathrm{BC}$, based on a couple of AMS dates, but was well established in the Ganges from around $2000 \mathrm{BC}$. That this was a gradual process may be indicated by slightly later evidence at other sites such as Mahagara (from 1800 BC) in which rice and native millets (but not Setaria pumila, mainly Brachiaria ramosa) are present in the lowest level with mungbean (from South India), winter cereals (barley and wheat) and lentil later in the sequence (Harvey et al. 2006; Harvey 2006). Preliminary observations on Neolithic plant remains from the sites of Tokwa and Jhusi suggest a similar mixed cultivation system was well established before the end of the Neolithic (Pokharia 2008-but see discussion of dating problems in Fuller 2011 supplement). All of this may point towards most of our evidence coming from the end of the process of agricultural origins in this region, as rice/ wheat/pulse-cultivating sedentary villages with domestic livestock become widely established. I think it is not an accident that this really takes off after $2000 \mathrm{BC}$, when there is evidence for a "Chinese horizon" of crop introductions in northwest India and Pakistan (peach, apricot, Panicum miliaceum, prob. Setaria italica, Cannabis sativa, hand harvest knives). Of these species Cannabis has names in India that point linguistically to Central Asian connections (Witzel 2005). This represents the earliest and best archaeological evidence for anything coming out of China and into South Asia. Of note is that this is just in the centuries after the first arrival into China of things from the west, such as taurine cattle, sheep, wheat and barley (see, e.g. Flad et al. 2010; Frachetti et al. 2010). Along with these other plants, I have hypothesized also the introduction of japonica rice, and its key nuclear mutations for domestication traits, into the proto-indica cultivars with a distinct chloroplast genetic background (see Fuller and Qin 2009; Fuller et al. 2010a). In linguistic terms, it should be noted that this would clearly be a process of loans of Chinese crops, and an approach to harvesting, probably via middlemen and not via immigrants, i.e. trade rather than demic diffusion (Fig. 4).

Why not an introduction of japonica rice from the northeast? Proponents of the Austric-farming-dispersal hypothesis (e.g. Bellwood 1996; Higham 2003) have often assumed that rice farming spread from Yunnan through Assam and into the Ganges. Others suggest that indica rice came from Southwest China (i.e. Yunnan), perhaps amongst early Austroasiatic speakers (Sagart 2008: 138) or perhaps that Northeast India 


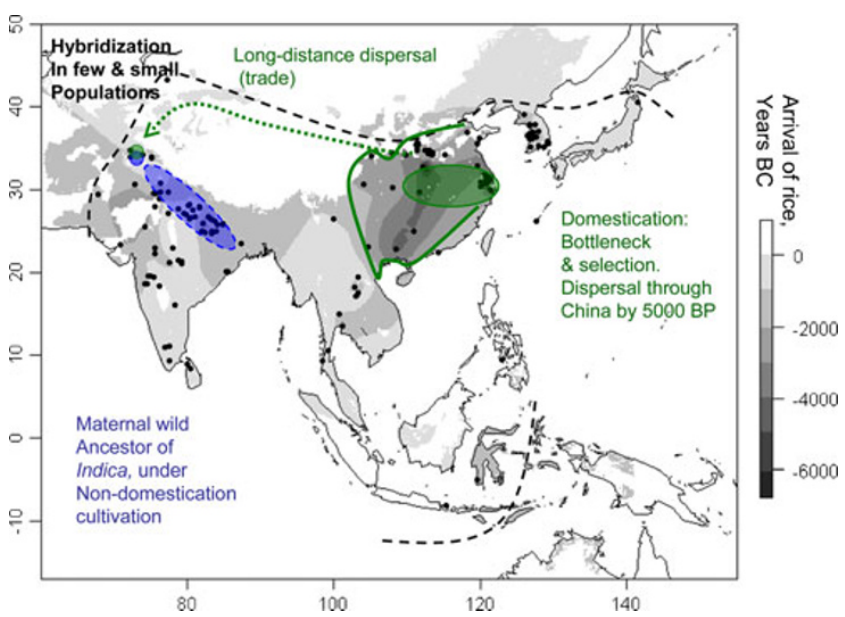

Fig. 4 Maps of the proto-indica hybridization hypothesis in space and time. The base map shows a geographical interpolation of the spread of rice (from Fuller et al. 2011b). In green is the focus of an early selection regime of japonica domestication and its initial dispersal zone, including northwards into the temperate zone. Blue indicates the potential spread of proto-indica exploitation and non-intensive cultivation, without major selection for domestication traits. Most of the spread in South Asia took place after hybridization.

will eventually prove to be a rice domestication area and/or a staging post in the spread or rice from China to India (Van Driem 2011a, b). However, any evidence for this, in terms of ceramic types, settlement patterns or archaeobotany is lacking. Admittedly Burma, Assam, Yunnana and Bengal are amongst the least well-known regions archaeobotanically and archaeologically - archaeology is very geographically biased (a point emphasized by Van Driem). Nevertheless based on current evidence, which is rapidly improving for Yunnan at least, the earliest rice farming in the upper Yangtze dates only from 2500-2000 BC at the earliest. It is of similar date in Orissa in eastern India and more or less of similar age in the Ganges. This gives insufficient time for such a spread, and if it had been quite so rapid one would expect more of an archaeological smoking gun, certainly on par with the Longshantype harvest knives that were being made and used in Kashmir and Swat after 2000 BC. As for crops that did come from the far northeast of India and/or the Yangtze into the Ganges, such as Citrus trees, cultivated mango and the fibre crop ramie (Boehmeria nivea), these are all evident in middle Ganges sites from about 1400 BC onwards (see Saraswat 2004, 2005; Kingwell-Banham and Fuller 2011). This in my opinion indicates the first evidence for agricultural diffusion into the Indian plains via Assam. I make a distinction here of the plains, because Munda speakers in all likelihood did migrate in from the northeast, but with a preference of hill habitats (as per Fuller 2003; Harvey et al. 2006; and contra Fuller 2007; Donegan and Stampe 2004 hypothesis on Austroastiatic origins). This is likely to have involved vegeculture (especially taro), shifting cultivation, and rice, but perhaps more likely aus rice than japonica.

\section{Can this be accommodated to a single origin of rice?}

It is important to be clear on what is meant by "origins", and I take the origins of rice to refer to independent traditions of economic reliance and/or management or cultivation of rice populations. As should already be clear, I regard the independent rice tradition of north India as never having proceeded on its own to full domestication. However, it is also possible that local domestication genes were later removed by drift once mutations with equivalent function were introduced from japonica (Allaby 2010). It should be clarified that I use domestication in the sense of a set of biological adaptations (of the plant) to the cultivated environment. Cultivation is a human activity; domestication is a genetic change in the plant (following the pedigree of Helbaek 1960; Harlan 1975; Harris 1989; Fuller et al. 2010b). The modern genetic evidence seems clear that many domestication traits had a single origin in terms of a single controlling mutation. These mutations, however, could then have been introduced into other lineages of managed/cultivated rice, as outlined above, via hybridization. It should also be clarified that "domestication event" as used in phylogenetic studies refers to the sub-sampling process of wild populations (perhaps with the beginnings of cultivation, but see Allaby 2010), whereas domestication refers to the fixation of genotypes adapted to cultivation.

A recent study by Molina et al. (2011a) carried out analysis of demographic history by attempting to model demographic parameters from several phylogenetic datasets using the new generation of collascent models which allow for multiple branches, bottlenecks and populations. Like the earlier conclusions of Vaughan et al. (2008), they conclude that single domestication of japonica is likely with indica derived from a subsequent bottleneck. This study, however, does not sway me from my conclusion about the evidence for a proto-indica exploited in India before the introduction and hybridization with improved japonica, but instead it reinforces the need for a fossil record, namely archaeobotany, to play critic to the computer-generated art of modelling, and to remind us that samples from the modern time plane can never capture lost genetic diversity of extirpated wild and cultivated lines of the past (Fig. 2). It is less about a failure to account for existing sub-population structure within modern wild rice (Ge and Sang 2011), since their model has provided some tests for this (Molina et al. 2011b), but that they are unable to sample and model the full range of diversity in all the lineages that have ever been cultivated, however briefly, over the past 8,000 years. The evidence from rice chloroplast genetics implies as much, since the chloroplast differs fundamentally between indica and japonica, nivara and rufipogon, such that there are shared characters between indica and nivara. Other characters in indica are unknown in the wild: extinct proto-indica lines are implied by the chloroplasts (Takahashi et al. 2008). Since 
chloroplasts are not carried in pollen, pollen from wild Indian rices introduced to japonica is insufficient explanation. Instead it seems still easier to posit proto-indica cultivation into which cultivated japonica, with a suite of valuable domestication traits, was brought into contact. The genetic background was largely indica into which japonica was the source of introgression, i.e. pollen flow. Nevertheless Molina et al. (2011a) recognize the role of hybridizations in their concluding discussion, and they are right to highlight the importance of incomplete lineage sorting in ancestral populations and that ancestral polymorphisms may have lead to overestimates in previous molecular clock calculations. Indeed, one of the more intriguing outcomes of their analysis are the new estimates for the age of bottlenecks, with an initial domestication placed as modally 8200 BP, and the indica bottleneck at 3900 BP. The former fits quite well with current archaeobotanical evidence for the beginnings of morphological change in Yangtze rice, i.e. just before the foundation of Kuahuqiao in the Lower Yangtze or in middle Yangtze terms during the later Pengtoushan culture (cf. Fuller and Qin 2009, 2010). The latter date is spot on for the first appearance of the "Chinese horizon" in Pakistan and northwest India. This study may be picking up on the history of the main stream of fully domesticated rice.

\section{Searching for domestication: early cultivators in China}

At present there is a surfeit of evidence for changes in the rice plant that indicate domestication but there is a surplus of claims and proclamations for the earliest rice, the earliest agriculture. The excavation teams of pretty much any late Pleistocene cave or Early Holocene settlement in South China have laid claim to theirs being the site and area of earliest rice farming. Archaeobotanical evidence in support of this which can stand up to scrutiny has been less forthcoming. I do not here want to repeat critiques of a few years ago (Fuller et al. 2007, 2008), which in the context of Hemudu culture have been vindicated by extensive systematic sampling at Tianluoshan (Fuller et al. 2009, 2011a), but will summarize the current state of the evidence. It is now clear that the early ceramics of 18,000-15,000 years ago are not associated with early farmers (Zhang and Hung 2008; Boaretto et al. 2009; Lu 2011). Instead it is in the period of $10,000-8,000$ years ago that cultivation began, with fixation of domestication traits closer to 6,000 years ago (Fuller et al. 2010a).

In recent years there has been an explosion of archaeobotanical research in China, and methodologically there have been major improvements such as the collection and study of spikelet bases (Fuller et al. 2009, 2010a). Four regions have emerged as candidates for early cultivation of rice (shown in Fig. 1): the Middle Yangtze, the Huai River and southwest Henan, the Houli culture of Shandong and the Lower Yangtze. Unfortunately these regions are not equal in terms of hard evidence, and it remains the case that only the Lower Yangzte has published morphological and quantitative evidence for the domestication process as it happened, and only for the latter half of the process (Fuller and Qin 2010). Other regions may have been places where wild rice was collected, where it was under pre-domestication cultivation, or even where selection for domestication traits was taking place, but we simply do not know. Some regions may have been dead ends in relation to the traditions of rice agriculture and the genetic lines that persist to this day. This is very likely the case for Shandong where the few finds show no continuity in later cultures (the Beixin and early Dawenkou are millet focused, with rice apparently reintroduced during the Dawenkou period: Song 2011). As for Jiahu, the earliest site with rice on the Huai river (7000-6000 BC), we still lack any evidence of spikelet bases, or clear trends of grain shape evolution, or the development of a weed flora, or any clear successor sites-was it a dead end of collectors or early cultivators or something more central to later traditions? - the evidence simply remains unclear. Material culture traits shared with the Yellow River region on the one hand and Yangtze Neolithic on the other may have much to do with this site's peripheral position to both cultural worlds, rather than indicating some core source of all of China's Neolithic as Cohen (2011) seems to imply (also contra Sagart 2008). Further to the south and west in Henan, new data from the lowest levels of the site of Baligang do suggest that non-shattering rice was evolving and being cultivated here alongside acorn gathering by ca. 6000 BC (unpublished observations), ${ }^{1}$ but the excavations to this level were so limited as to leave material cultural affinities totally unclear. In the middle Yangtze, archaeobotanical evidence is rather more diverse, from Bashidang and Chengtoushan, but we once again lack clear domestication indicators. Cultivation is clear from the weed flora at Chengtoushan, ca. 4300-3800 BC (Nasu et al. 2011), and the cultivation system does appear to differ from that of later Hemudu or Majiabang cultures (cf. Fuller and Qin 2009). I tend to favour a diffuse and multi-centric model in which parallel processes of early rice cultivation began de novo in more than one part of China, a position which derives from an emphasis on archaeological cultural differences between regions which are more or less contemporary and the lack of clear evidence for any intensive interaction or trade, but this is not to deny some underlying cultural affinity along the lines of more ancient shared Palaeolithic traditions based on cooking pots and understandings of bodily substance (Fuller and Rowlands 2009, 2011). This appears to be similar to the better known case of the Near East in which early cultivation and the

\footnotetext{
${ }^{1}$ With special thanks to Fan Li (deceased), Zhang Chi and Qin Ling for hosting me at the excavations and allowing me to look at floats.
} 
appearance of domesticates appears to be a diffuse process across a wide region rather than focused on any one core region (Willcox 2005; Allaby et al. 2010; Fuller et al. 2011c, d). In the Near East, this was built upon a much older shared tradition of grain-grinding, flour-based foods and roast meats (Fuller and Rowlands 2009, 2011).

Evidence for the end of the domestication process is better, with both a growing quantity of archaeobotanical evidence and preserved field systems. Direct evidence for intensive wet rice agriculture comes from preserved field systems, found at two sites in the Lower Yangzte at 4200-3800 BC, Chuodun and Caoxieshan, and one site in the Middle Yangzte at ca. 4500 BC (Chengtoushan, Fuller and Qin 2009; Nasu et al. 2011). Such systems were labour intensive but must have also supported growing populations: they are likely correlates of the demographic explosion that would have driven outward migrations.

\section{The spread of rice and wet rice: demographic implications and thoughts on language hypotheses}

Over the past few years, together with research students, post-docs and some colleagues from abroad, we have compiled a rice database. It is by no means comprehensive in terms of recording every stray report of archaeological rice, but it is complete, so far as I am aware, in terms of systematically collected and studied archaeobotanical data from continental Asia (published to date), and where geographical and chronological gaps are to be found in the evidence, these regions have been filled with whatever haphazard evidence for rice there is, from stray hand-collected rice grains to husk-tempered ceramic sherds. On the basis of this growing rice database, we published a summary of the spread of rice in "11 thrusts" (Fuller et al. 2010a). This lead onto a model of the spread and infilling of the map with wet rice, which provides an estimate of the potential atmospheric methane that came from flooded rice fields and how that amount increased over the course of the Holocene (Fuller et al. 2011b). While this has an important role to play in terms of assessing the contribution of rice to anthropogenic climate impacts over the past 5,000 years (see Ruddiman et al. 2011), this model can also be considered to a provide a partial demographic proxy. Wet rice is more productive and more labour intensive: it supports as well as requires higher populations. Below I revisit eight of the "thrusts" of dispersal together with suggested correlations with past language spreads. In linguistic terms, I follow my previous work on South Asia (Fuller 2003, 2007) while for East and Southeast Asia I attempt to chart a middle ground synthesis from among the thinking by Blench $(2005,2008 \mathrm{a}, 2010 \mathrm{a}$, b), Van Driem (2011a, b) and Sagart (2003, 2008, this volume).
The northern thrust and early temperate japonica

This represents the first northward dispersal of rice from the Yangtze (and/or Huai) region. This is an important expansion event in which rice reached north of the Qinling Mountains quite separated from the wild rices of the Yangtze watershed. This happened from about 6,000 years ago, and much more extensively by 5,000 years ago, and judging by grain size (Qin and Fuller 2009) is likely to have involved evolution of an early form of short-grained temperate japonica. This probably implies a genetic bottleneck in rice, secondary to a bottleneck of initial cultivation and any bottlenecks involved with postPleistocene expansion.

It should be emphasized that this rice was adopted on a small scale into a well-established regional cultural tradition (the Early Yangshao), which was mostly dependent on millet cultivation, as well as into the Dawenkou culture of Shandong (Fig. 5). The beginnings of millet cultivation are poorly understood, but date back to at least $6000 \mathrm{BC}$, and probably have their origin in mobile hunter-gatherers societies of Early Holocene north China (Bettinger et al. 2010; Zhao 2011; Cohen 2011), in opposition to the sedentary collectors who developed rice cultivation. There is little basis for postulating a single centre for all Chinese millet origins, but instead there is a scatter of cultures (Dadiwan, Peilingang, Cishan, Houli, Xinglongwa) which seem to be settling into more sedentary millet agriculture around 6000 5500 BC (Liu et al. 2009). ${ }^{2}$ Some of these groups may be dead ends in the sense that more developed sedentary millet farming replaced earlier traditions during the Yangshao cultural expansion. There no reason to infer that all the early millet cultural groups were culturally or linguistically uniform. Some the early millet cultures probably fit into "macro-Altaic" (including Tungasic, Koreanic, Blench 2005), judging by the later spread of millet agriculture to eastern Siberia (Primorye) and Korea from ca. 3500 BC (Sergusheva and Vostretsov 2009; Lee 2011). The Yangshao phenomenon was expansive, and this seems likely to have involved, in some measure, demographic expansion that pushed outwards and incorporated areas like southern Gansu (formerly Dadiwan culture).

Given the continuity from the Yangshao, the Longshan and hence the Bronze Age, it is hard to imagine the Yangshao, millet and pig-focused with added rice, being other than related to the Sinitic linguistic line. Indeed, Sagart (2008) has postulated that familiarity with foxtail millet $(S$. italica), by far the dominant cereal throughout the Yellow River region through the Yangshao and Longshan phases (Song 2011), can be reconstructed for and early Sino-

\footnotetext{
${ }^{2}$ Hard archaeobotanical evidence for tracking the domestication process in S. italica or P. miliaceum, or for distinguishing cultivation from gathering, is so far lacking.
} 
Tibetan and indeed for his hypothesized STAN, which would link this to Austronesian. Whether this link really needs to be a linguistic-genetic one, and not a case of early interaction and loans, perhaps needs clarification.

Blench (2005) and Blench and Post (2010) suggested it is difficult to derive all of Sino-Tibetan from shared agricultural origins, and posit hunter-gatherer origins along the eastern Himalaya. However, ruling out that hunter-gatherers substrates were not later incorporated into Sino-Tibetan seems difficult. Therefore in Fig. 5, I have indicated some early foragers around the eastern front of the Himalayas, which might have been either pre-agricultural Sino-Tibetan relatives (as per Blench and Post 2010) or later absorbed by Sino-Tibetan farmers. Sagart reports shared vocabulary for rice between (some) Sino-Tibetan (focused on Sinitic) and Austronesian, but rather than seeing these as deriving from the domestication of rice by the same group who started millet cultivation, the archaeology is more in keeping with an introduction of rice into millet farming.

Archaeobotanical evidence is clearly against the older notion that millet agriculture developed as rice farmers moved north (Fuller et al. 2007; Zhao 2011; Song 2011). Instead it makes sense that terms relating to rice are loans to Sino-Tibetan from early rice-growing Hmong-Mien [=Miao-Yao] (Van Driem 2011a, b). Indeed Hmong-Mien is a popular candidate group for rice domesticators, perhaps those focused on the middle Yangtze (Blench 2005; Van Driem 2011a). The Yangshao archaeobotanical evidence suggests a minimal age of 3800-4000 BC (Qin and Fuller 2009) on the introduction of rice from Hmong-Mien to ST (or STAN), which may therefore help to date some of the separation of ST or STAN languages.

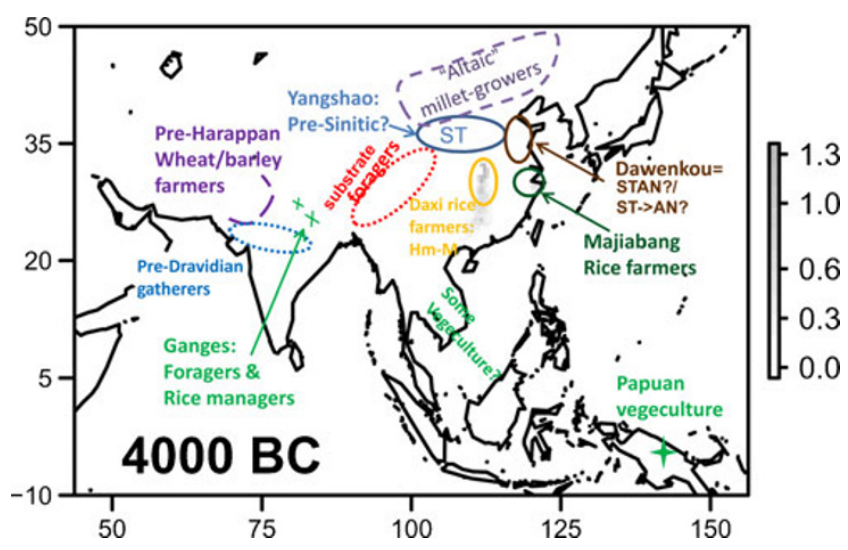

Fig. 5 Some general hypotheses linking the distribution of subsistence cultures and language affiliation for ca. $4000 \mathrm{BC}$. The basemap is from Fuller et al. (2011b) and shows in grey a reconstruction of land area under wet rice cultivation as a percentage of modern wet rice land area (the percentage scale is indicated in the shaded bar at the right). It is presumed that wet rice supported denser and expanding human populations. Language family abbreviations: $A N$ Austronesian, $H m-M$ Hmong-Mien, STAN Sino-Tibetan-Austronesian (of Sagart 2008).
An earlier Jomon and Chulmun upland japonica?

While the hypothesis that some upland rice reached Korea and Japan in the Second Millennium BC seems reasonable (Fuller et al. 2010a; Tanaka et al. 2010), the big demographic growth presumably came with paddy fields in the first millennium BC with the Mumun and Yayoi periods. The spread of paddy fields was defined as "thrust 9" (Fuller et al. 2010a), but is not taken up further here. The linguistic evidence for an extensive proto-Japonic rice terminology is clear, but where these terms of the Japanese language originated is not (see Blench 2005). The recent claim that the Yayoi elite were immigrants who brought rice from Java (Kumar 2009) has little merit (Fuller 2010), and there remains little to support a major migration from the south. Nevertheless, if Proto-Austronesian precursors were placed along the Jiangsu/Shandong coastline, as Sagart's (2008) hypothesis suggests, then some Austronesian-related terminology should be expected to have made its way into Korea and Japan, since the source of Korean, and ultimately Japanese, rice is likely Shandong (Ahn 2010). Early pre-Yayoi rice would have been an upland form, presumably with low productivity and likely little different from millets. The Mumun and Yayoi rices, by contrast, were grown in wet paddy fields, and would have provided higher productivity and greater demographic increase.

To Taiwan and beyond: a southerly quasi-temperate japonica

This represents the start of the classic early Austronesian dispersal hypothesis, in which demographic growth amongst rice and millet farmers in Taiwan from around 2500 BC fuels onwards migration southward (Bellwood 1996, 1997). Rice appears in Taiwan along with foxtail millet in the early third millennium $\mathrm{BC}$, presumably with the spread of agriculture from somewhere in mainland China (Tsang 2005). Quality archaeobotanical evidence from Taiwan is still lacking, so that we can say little about the variation in the rice or how it was cultivated, although published photographs suggest a shorter grained form, which would point towards the Yellow River rather than the Yangtze region as a source zone, as does the millet. The absence of $P$. miliaceum so far in Taiwan is curious, as this is almost always found together with foxtail millet on the mainland (Song 2011), and has traditional importance amongst some Formosan-speaking groups in the hills of Taiwan (Fogg 1983). Together with Dawenkou-Nanguanli tendencies toward tooth evulsion practices, these thin data do tally with Sagart's suggested derivation of the early Taiwanese crops and AN speakers from Eastern China around South Shandong or Jiangsu (Fig. 6). Nevertheless, in terms of archaeological culture, there is clearly close ties 


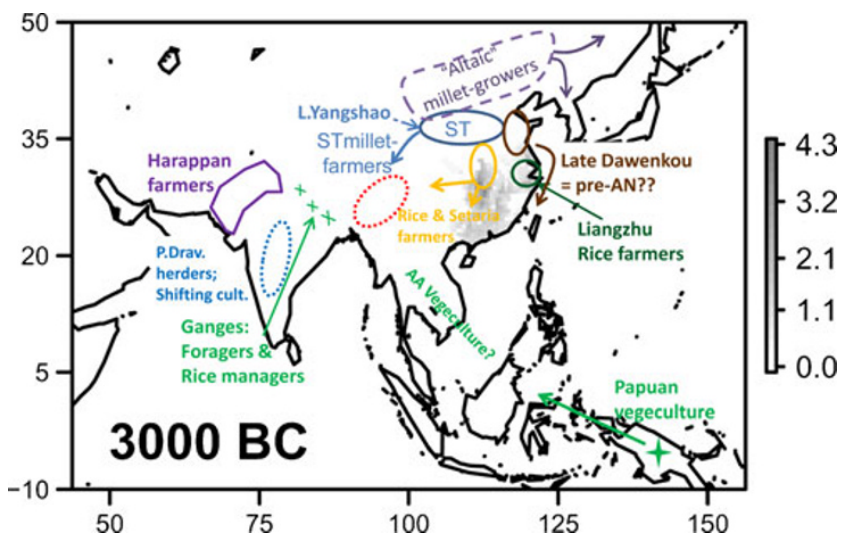

Fig. 6 Some hypotheses linking the distribution of subsistence cultures and language affiliation for ca. $3000 \mathrm{BC}$, with indication of the dispersal directions for north Chinese millets, middle Yangtze rice and millet systems, and possible Dawenkou-related coastal dispersal southwards (Tanshishan and Nanguanli). The basemap is from Fuller et al. (2011b) and shows in grey a reconstruction of land area under wet rice cultivation as a percentage of modern wet rice land area (the percentage scale is indicated in the shaded bar at the right). It is presumed that wet rice supported denser and expanding human populations. Language family abbreviations: $A A$ Austroasiatic, AN Austronesian, P.Drav. ProtoDravidian, $S T$ Sino-Tibetan

between Taiwan and Fujian (Tanshishan culture), but coastal Fujian archaeology suggests a greater importance of fish and shell fish instead of agriculture (Rolett et al. 2011), and thus lacks an agricultural demographic motor. But perhaps we need to postulate cultural hybridity of some sort with the traditions of Fujian and coastally focused immigrants from north of the Yangtze. There are no clear material culture links, or strong cultural affinities between Taiwan/Fujian and the freshwater Lower Yangtze culture, despite generations of hopeful thinking (e.g. Jiao 2006), and archaeology has been so intensive around the Lower Yangtze for this period that it is hard to accept that we have missed such evidence. During the third millennium, the elite culture of the Lower Yangtze (Liangzhu) through its jade art had wide reaching influences on other parts of China (including Dawenkou, Early Longshan, etc.), but in many ways it was an inward-looking culture little influenced by other areas. If I were guessing, I would see the Lower Yangtze as most likely a region of an isolated or extinct language distinct from the coastal Austronesian-related groups.

From Taiwan rice spread further (Fig. 7), but its importance in island Southeast Asia appears limited and hard evidence is scarce. Growing evidence suggests both that some arboricultural and vegecultural economies were already established in parts of island Southeast Asia, perhaps related to the independent development of cultivation in New Guinea (Donohue and Denham 2010), and that substrate languages in island southeast Asia (which probably included some Austroasiatic taro farmers) were later subsumed by Austronesian dominance (Blench 2010a, b). Genetic evidence is clear that pigs in most

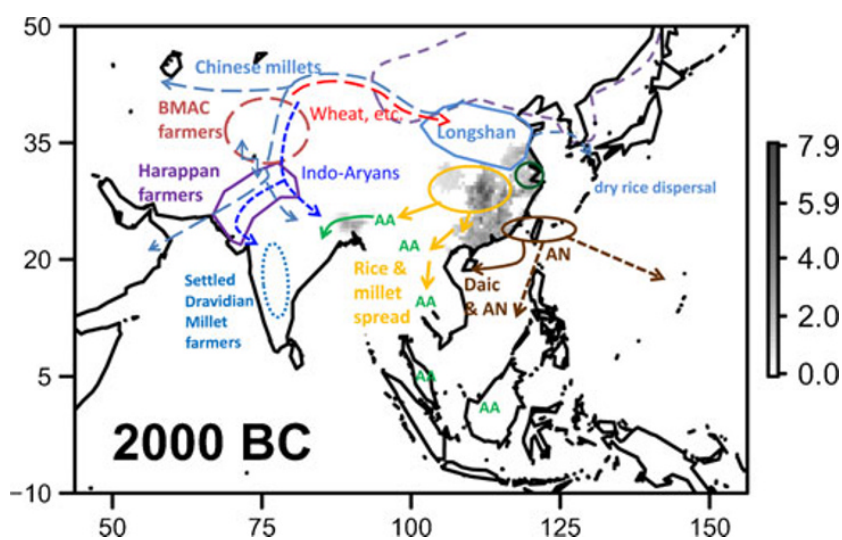

Fig. 7 Some hypotheses linking the distribution of subsistence cultures and language affiliation for ca. 2000 BC. Indicated are the crop dispersal towards Southeast Asia and the diffusion of western crops into Longshan China, and Chinese crops, notable millets westwards and southwards (to South Asia, Yemen, Sudan). The basemap is from Fuller et al. (2011b) and shows in grey a reconstruction of land area under wet rice cultivation as a percentage of modern wet rice land area (the percentage scale is indicated in the shaded bar at the right). It is preseumed that wet rice supported denser and expanding human populations. The Bactria-Margiana Archaeological Complex $(B M A C)$ is indicated. Language family abbreviations: $A A$ Austroasiatic, $A N$ Austronesian, $S T$ Sino-Tibetan. Munda languages are included in the Austroasiatic family.

of the region and the pacific beyond were introduced from a mainland Southeast Asian domestication (northern Vietnam/ Yunnan) (Larson et al. 2010). On the other hand, coastal dispersal around southern China and to Vietnam could have been important (Zhang and Hung 2010). The early evidence of rice in mainland Southeast Asia focuses on the lower courses of rivers rather than their upper courses of the interior (Castillo and Fuller 2010). Some of this coastal spread (Sagart 2008; this volume) can be seen as the earliest spread of TaiKadai speakers, who subsequently moved inland, up rivers. This hypothesis has been supported by Blench (2008b), who attributes ethnographic traditions of tooth evulsion, facial tattooing, multi-tongue mouth harps and snake cults to this ancestry.

\section{Proto-indica origins and spread}

The case for early rice use in the Ganges has been dealt with in detail. Reports from northwest India and northern Pakistan suggest that some rice was consumed, and presumably planted, within this wheat- and barley-dominated zone, already during the Harappan era (2500-2000 BC), although spikelet bases to determine domestication status are so far unavailable. It is possible that some domestication nonshattering had evolved here but, if so, was subsequently replaced by introduced japonica mutations including sh4. And it is in this context that hybridization with japonica is hypothesized (at the end of this period after 2000 BC). 
Linguistically, northwest India and the Ganges both provide evidence for extensive substrate language influence on the later intrusive Indo-Aryan, possibly including two distinct language phyla (Witzel 1999, 2005; Southworth 2005; Fuller 2007). These languages left a lasting impact on Indian agricultural vocabulary, as well as that for local flora, some fauna, and dance. That they were subsumed in Indo-Aryan languages is no doubt partly due to elite dominance in the post-Harappan world, but the demographic impact of true rice agriculture, with improved hybridized domesticates, should be considered as a major motor in the rise to dominance Indo-Ayran speakers and their internal spread within India (Fig. 7). Their rice was rotated with pulses, wheat and barley, and fully integrated with pastoralism. It is not surprising then that during the second millennium $\mathrm{BC}$, large sedentary settlements become widespread throughout the Ganges and eastern India (the plains of Orissa).

\section{Tropical japonica from South China to Southeast Asia}

In addition to potential coastal spread from Fujian or Taiwan, there appears to be the spread of upland rain-fed rice and foxtail millets through the hills of south China (Guangdong, Guangxi) and into the upland zones of Southeast Asia, perhaps 2500 to 2000 BC (Castillo and Fuller 2010; Castillo 2011), ultimately from the Daxi-Qiujialing tradition of the middle Yangtze (Figs. 5, 6 and 7). In some regions, hinted at by recent archaeobotanical evidence from central Thailand (Weber et al. 2010), rice may have been abandoned for a focus on millets, with rice only becoming important again later on, as social complexity increased (see Castillo 2011). Whether this early spread included some early Austroasiatic speakers (AA) is unclear, but as suggested by Blench (2005) much of their shared vocabulary points to a hill cultivation and swidden culture, in which taro (Colocasia esculenta) would have been present alongside rice. This would seem at odds with the notion that they spread mainly along rivers (as per Higham 2003), but it may be that there were several different waves of Austroasiatic with a rice-millet wave overlying an earlier vegecultural wave, which might help to account for their widespread diversity. Might we also see some early TaiKadai speakers in this area? It is presumably to this period that western Austroasiatics, as pre-Proto-Munda speakers (the westward AA arrow in Fig. 7), also focused on islands of hill forest habitat and shifting cultivation moved into India towards the hills of Orissa (Fuller 2003). Once into areas near the Indian peninsula (perhaps broadly around $2000 \mathrm{BC}$ or the centuries after), these farmers picked up native Indian millets and pulses and domesticated sheep, goat and zebu, in some cases apparently with connected early Dravidian vocabulary. At this time the plains were already occupied by more intensive, and probably denser, rice farmers. The potential role of a distinct domestication of aus rices connected to all or part of the Austroasiatic expansion needs research. The genetic evidence of McNally et al. (2009) indicates that aus genomes have seen substantial hybridization both with japonica and indica rice, which hints at a complex history of dispersal and cultural interactions involved in the spread of rice within and through the greater Bengal-Assam-Burma region.

\section{Carry on up the Yangtze}

Rice cultivation also spread up the Yangtze river into the Sichuan basin and to Yunnan, but there is no evidence to put this much before ca. 3000-2500 BC for Sichuan or much before 2000 BC for Yunnan. Thus this spread took place at about the same time as the coastal and overland spread southwards out of the Yangtze, and early spreads of protoindica in India. Taken with the other spreads of japonica, we can infer the motor of a fairly major demographic "upwelling" in the middle Yangtze and the plains of eastern China by about 3000 BC (Fig. 6). This seems likely the result of a millennium or so of intensive paddy cultivation based on fully morphologically domesticated rice. What was different about the trajectory up the Yangtze was a focus on wet field rice, whereas the Southeast Asian trajectory probably involved dry rice. In addition, there appears to have been a separate spread of millet cultivation at higher elevations along the eastern front of the Tibetan plateau, coming down from Gansu (Majiayao culture). Judging by millet finds in western Sichuan and the dates of Changdu Karuo of perhaps 3000 BC (see Guedes 2011), the spread of millets, presumably with some hill-focused lineages of Sino-Tibetan, was earlier than the upriver dispersal of wet rice. Is there any substrate evidence for Hmong-Mien in the Sichuan or Yunnan plains, given their postulated presence in the Middle Yangtze? Otherwise we perhaps must postulate the presence of another branch of Austroasiatic, presumably distinct from the vegeculturalists of further south. In any case, whatever languages were spoken in Sichuan, their speakers might have received rice brought upriver from the middle Yangtze together with vocabulary descended from the same source as the earlier loans from the middle Yangtzte (HmongMien?) to Yellow River languages (Sino-Tibetan), so disentangling genetic cognates with Sino-Tibetan from two strata of ancient loans from the same source may be a challenge.

The introduction of japonica genes and the making of indica

This has already been reviewed more extensively above (Fig. 4). This clearly took place in the context of growing central Asian trade, including most proximally to South Asia the Batria-Margiana Archaeological Complex of 
fortified cities, and a broader Middle Asian Interaction sphere (Fig. 7), by which Chinese Panicum millet was to reach Yemen and Sudan by 2000-1700 BC (Boivin and Fuller 2009). Even if, genetically, the Panicum millets of South Asia prove on the whole to have a larger genetic input from a distinct west/central Asian Panicum domestication, there was still some genetic input from Chinese millets (see Hunt et al. 2011), and the spread of crops into northwestern South Asia was clearly important just after 4,000 years ago. This period was also one of transportation revolutions on the margins of South and Central Asia, including the first clear evidence for the use of Bactrian camels and horses in the Indus region (Meadow 1996). These processes of trade and improved means of transport probably facilitated some of the waves of Indo-Aryans who came into South Asia. This was also an era of drier climate (Madella and Fuller 2006) that may have pushed people from the deserts of central Asia towards the wetter valleys like the Indus and into the monsoon zone. Although they are symptomatic of the same processes, there is no reason to postulate a direct connection between Indo-Aryan arrival and japonica rice arrival in South Asia.

The dispersal of rice throughout South Asia and beyond

The available weed data from the Ganges suggest that early rice cultivation was essentially dry cropping, based on monsoon rains and seasonal flood recession, but that plausible wet field irrigated rice may have been grown by the end of the second millennium BC and certainly by the Iron Age (Fuller and Qin 2009). Agricultural intensification in this period is indicated by the adoption of cash crops like cotton and flax, and may be linked to the emergence of social hierarchy (Fuller 2008). It is only during the Iron Age that rice cultivation (and paddies) became more widely established through South India

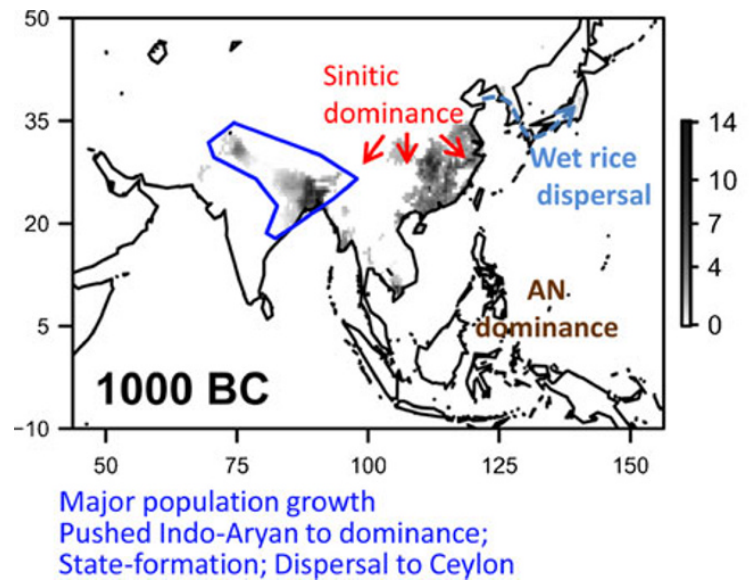

Fig. 8 Some hypotheses relating the rise to dominance of regional languages and state formation built on the infilling of Asian landscapes with intensive rice agriculture. The basemap is from Fuller et al. (2011b) and shows in grey a reconstruction of land area under wet rice and were introduced to Sri Lanka (Fig. 8). In Sri Lanka and Tamil Nadu, the first rice seems to be associated with the construction of larger irrigation tanks and the emergence of hierarchical and sedentary societies. The advent of rice in the far South must have prompted dramatic population growth, and this may account for the very widespread distribution of the some Dravidian languages, such as Old Tamil. This demographic pulse was additional to an older Neolithic expansion process associated with the earliest agriculture in South India [based on native millets and pulses, as well as livestock (Southworth 2005; Fuller 2003, 2007, 2011)]. Once these societies became rice-growing societies, they played an increasing role in long distance trade, such as the spice trade that the Roman empire tapped into. There was also trade established during the first millennium $\mathrm{BC}$ between India and Southeast Asia (Fuller et al. 2011b), and it is possible that the first lowland indica rices in Southeast Asia came by this means. Rice from India also came to get established in Lower Mesopotamia in the late centuries BC (Nesbitt et al. 2010).

\section{Concluding remarks}

While there remains much to discuss and debate on the origins and spread of rice, as well as how this relates to language histories, it is most important that we recognize that gaps in our knowledge - especially geographical gaps in archaeological data-limit the reliability of some of the reconstructions presented above. Nevertheless, current evidence, as outlined, provides a clear context in which to frame new research in the gaps (such as Assam, Myanmar), but also for framing updated historical linguistic hypotheses. The archaeobotanical evidence is important for informing genetic models and agricultural language models. In general the archaeological record points to processes of diffusion

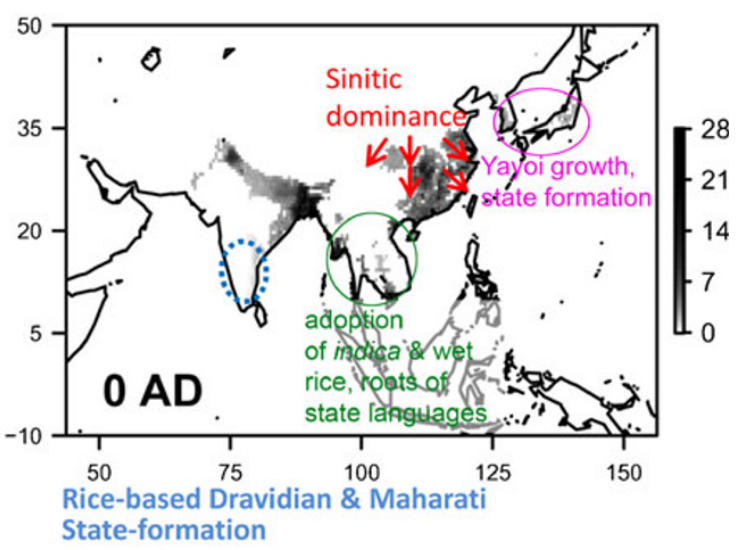

cultivation as a percentage of modern wet rice land area (the percentage scale is indicated in the shaded bar at the right). AN Austronesian languages. 
and adoption alongside those of migration to parallel evolution as well as inspiration. Historical linguistic models and the agricultural/language dispersal hypothesis (Bellwood 2011) may tend to emphasize the migration of farmers, but this is only part of the story, as both the genetics of hybridized genomes and archaeological evidence indicate. As emphasized by Blench (2008a, b, 2011b), for example, and well discussed in South Asian linguistics circles (Witzel 1999, 2005; Southworth 2005; Fuller 2007), there is widespread evidence for language substrates, both agricultural and pre-agricultural, and later state-related processes of dominance and linguistic flattening have tended to obscure some the earlier historical linguistic complexity. Similarly dominant trade languages have probably also aided in the reduction of linguistic diversity in some regions, as may have been the case with early Indo-Aryan, Malay and some earlier lects of Malayo-Polynesian. Just as modern DNA samples fail to capture some of the lost diversity, both cultivated and wild, of rice, linguistic reconstruction can only provide part of the picture. However, by triangulating between archaeological data points, modern genetic inferences and historical linguistics, we should be better placed to recapture and reconstruct patterns of evolutionary process and history that brought us to where we are today. There can be no doubt that the civilizations of Asia have histories in which rice has been a key component, both as staple foodstuff and as salient cultural symbol.

Acknowledgements The author is grateful to two thorough but rapid peer reviewers and the editorial comments from Magnus Fiskesjö and Caroline Hsing, all of which helped to improve and streamline this article. My ideas also benefitted from the discussion during the Rice \& Language across Asia symposium at Cornell, 22-25 September 2011. I was also was pleased to receive unpublished manuscripts on relevant linguistic issues from George Van Driem and Roger Blench.

\section{References}

Ahn S. The emergence of rice agriculture in Korea: archaeobotanical perspectives. Archaeol Anthropol Sci. 2010;2(2):89-98.

Allaby RG. Integrating the processes in the evolutionary system of domestication. J Exp Bot. 2010;61:935-44.

Allaby RG, Brown TA, Fuller DQ. A simulation of the effect of inbreeding on crop domestication genetics with comments on the integration of archaeobotany and genetics: a reply to Honne and Heun. Veget Hist Archaeobot. 2010;19(2):151-8.

Bellwood P. The origins and spread of agriculture in the Indo-pacific region: gradualism, diffusion or revolution and colonization. In: Harris DR, editor. The origins and spread of agriculture and pastoralism in Eurasia. London: UCL Press; 1996. p. 465-98.

Bellwood P. Prehistory of the Indo-Malaysian archipelago. 2nd ed. Honolulu: University of Hawaii Press; 1997.

Bellwood P. Holocene population history in the Pacific region as a model for worldwide food producer dispersals. Curr Anthropol. 2011;52(S4):S363-78.

Berger A. Long-term variations of caloric insolation resulting from the Earth's orbital elements. Quat Res. 1978;9:139-67.
Bettinger RL, Barton L, Morgan C. The origins of food production in north China: a different kind of agricultural revolution. Evol Anthropol. 2010;19:9-21.

Blench RM. From the mountains to the valleys: understanding ethnoliguistic geography in Southeast Asia. In: Blench RM, Sagart L, Sanchez-Mazas A, editors. Perspectives in the phylogeny of East Asian languages. London: Curzon; 2005. p. 31-50.

Blench RM. Stratification in the peopling of China. How far does the linguistic evidence match genetics and archaeology? In: SanchezMazas A, Blench R, Ross MD, Peiros I, Lin M, editors. Past human migrations in East Asia. Matching archaeology, linguistics and genetics. London: Routledge; 2008. p. 105-32.

Blench RM. The prehistory of Daic (Tai-Kadai) peoples and the Austronesian connection. Presentation at EURASEAA conference, Leiden, Sept. 2008. 2008b. www.rogerblench.info.

Blench RM. Was there an Austroasiatic presence in Island Southeast Asia prior to the Austronesian expansion? Bull Indo-Pac Prehist Assoc. 2010;30:133-44.

Blench, RM. Austronesians or Austronesianisation or why we should take the sociolinguistics of the past seriously. Presented at EURASEAA conference, Berlin. 2010b. Manuscript provided by the author in Dec 2010.

Blench RM and Post M. Rethinking Sino-Tibetan phylogeny from the perspective of Northern Indian languages. Paper from the 16th Himalayan Languages Symposium, SOAS, London. 2010. Manuscript provided by the author.

Blust R. Beyond the Austronesian homeland: the Austric hypothesis and its implications for archaeology. In: Goodenough WH, editor. Prehistoric settlement of the pacific. Philadelphia: American Philosophical Society; 1996. p. 117-60.

Boaretto E, Wu X, Yuan J, Bar-Yosef O, Chu V, Pan Y, et al. Radiocarbon dating of charcoal and bone collagen associated with early pottery at Yuchanyan Cave, Hunan Province, China. Proc Natl Acad Sci U S A. 2009;106:9595-600.

Boivin N, Fuller DQ. Shell middens, ships and seeds: exploring coastal subsistence, maritime trade and the dispersal of domesticates in and around the ancient Arabian Peninsula. J World Prehist. 2009;22:113-80.

Bray F. The rice economies: technology and development in Asian societies. Berkeley: University of California Press; 1994.

Burns SJ. Speleothem records of changes in tropical hydrology over the Holocene and possible implications for atmospheric methane. Holocene. 2011;21:735-41.

Castillo C. Rice in Thailand: the archaeobotanical contribution. Rice. 2011. doi:10.1007/s12284-011-9070-2.

Castillo C, Fuller DQ. Still too fragmentary and dependent upon chance? Advances in the study of early Southeast Asian archaeobotany. In: Bellina B, Bacus EA, Pryce O, Weissman Christie J, editors. 50 years of archaeology in Southeast Asia: essays in honour of Ian Glover. Bangkok: River Books; 2010. p. 91-111.

Cohen DJ. The beginnings of agriculture in China: a multiregional view. Curr Anthropol. 2011;52(S4):S273-93.

Donegan P, Stampe D. Rhythm and the synthetic drift of Munda. In: Singh R, editor. The yearbook of South Asian languages and linguistics 2004. Berlin: Mouton de Gruyter; 2004. p. 3-36.

Donohue M, Denham T. Farming and language in island Southeast Asia: reframing Austronesian history. Curr Anthropol. 2010;51(2):223-56.

Durkheim E, Mauss M. Note sur la notion de civilisation. Année Sociologique. 1913;12:46-50.

Flad R, Li S, Wu X, Zhao Z. Early wheat in China: results from new studies at Donghuishan in the Hexi Corridor. Holocene. 2010;20:955-65.

Fogg WH. Swidden cultivation of foxtail millet by Taiwan aborigines: a cultural analogue of the domestication of Setaria italics in China. In: Keightley DN, editor. The origins of Chinese civilization. Berkeley: University of California Press; 1983. p. 95-115. 
Frachetti MD, Spengler RN, Fritz GJ, Mar'yashev AN. Earliest direct evidence for broomcorn millet and wheat in the central Eurasian steppe region. Antiquity. 2010;84:993-1010.

Fuller DQ. Fifty Years of Archaeobotanical Studies in India: Laying a Solid Foundation. In Settar S, Korisettar R, editors. Indian Archaeology in Retrospect, Volume III. Archaeology and Interactive Disciplines. New Delhi: Manohar; 2002. p. 247-364.

Fuller DQ. An agricultural perspective on Dravidian historical linguistics: archaeological crop packages, livestock and Dravidian crop vocabulary. In: Bellwood P, Renfrew C, editors. Assessing the language/ farming dispersal hypothesis. Cambridge: McDonald Institute for Archaeological Research; 2003. p. 191-213.

Fuller DQ. Agricultural origins and frontiers in South Asia: a working synthesis. J World Prehist. 2006a;20(1):1-86.

Fuller DQ. Silence before sedentism and the advent of cash-crops: a status report on early agriculture in South Asia from plant domestication to the development of political economies (with an excursus on the problem of semantic shift among millets and rice). In: Osada $\mathrm{T}$, editor. Proceedings of the pre-symposium of RIHN and 7th ESCA Harvard-Kyoto Roundtable. Kyoto: Research Institute for Humanity and Nature; 2006b. p. 175-213.

Fuller DQ. Non-human genetics, agricultural origins, and historical linguistics. In: Petraglia M, Allchin B, editors. The evolution and history of human populations in South Asia. Inter-disciplinary studies in archaeology, biological anthropology, linguistics and genetics. Dordrecht: Springer; 2007. p. 393-443.

Fuller DQ. The spread of textile production and textile crops in India beyond the Harappan zone: An aspect of the emergence of craft specialization and systematic trade. In: Osada T, Uesugi A, editors. Linguistics, archaeology and the human past. Indus Project Occasional Paper 3. Kyoto: Indus Project, Research Institute for Humanity and Nature; 2008. pp. 1-26.

Fuller DQ. Book review of Kumar, globalizing the prehistory of Japan. Jpn Stud. 2010;30(1):137-41

Fuller DQ. Finding plant domestication in the Indian subcontinent. Curr Anthropol. 2011;52(S4):S347-62.

Fuller DQ, Qin L. Water management and labour in the origins and dispersal of Asian rice. World Archaeol. 2009;41(1):88-111.

Fuller DQ, Qin L. Declining oaks, increasing artistry, and cultivating rice: the environmental and social context of the emergence of farming in the Lower Yangtze Region. Environ Archaeol. 2010;15(2):139-59.

Fuller DQ, Rowlands M. Towards a long-term macro-geography of cultural substances: food and sacrifice traditions in East, West and South Asia. Chin Rev Anthropol. 2009;12:1-37.

Fuller DQ, Rowlands M. Ingestion and Food Technologies: Maintaining differences over the long-term in West, South and East Asia. In Wilkinson TC, Sherratt S, Bennet J, editors. Interweaving Worlds- systematic interactions in Eurasia, 7th to 1st millennia BC. Oxford: Oxbow Books; 2011. p. 37-60

Fuller DQ, Harvey E, Qin L. Presumed domestication? Evidence for wild rice cultivation and domestication in the fifth millennium BC of the lower Yangtze region. Antiquity. 2007;81:316-31.

Fuller DQ, Qin L, Harvey E. Evidence for a late onset of agriculture in the Lower Yangzi region and challenges for an archaeobotany of rice. In: Sanchez-Mazas A, Blench R, Ross MD, Peiros I, Lin M, editors. Past human migrations in East Asia. Matching archaeology, linguistics and genetics. London: Routledge; 2008. p. 40-83.

Fuller DQ, Qin L, Zhao Z, Zheng Y, Chen X, Hosoya L-A, et al. The domestication process and domestication rate in rice: spikelet bases from the Lower Yangtze. Science. 2009;323(5921):1607-10.

Fuller DQ, Sato Y, Castillo C, Qin L, Weisskopf AR, Kingwell-Banham EJ, et al. Consilience of genetics and archaeobotany in the entangled history of rice. Archaeol Anthropol Sci. 2010a;2:115-31.

Fuller DQ, Allaby RG, Stevens C. Domestication as innovation: the entanglement of techniques, technology and chance in the domestication of cereal crops. World Archaeol. 2010b;42(1):13-28.
Fuller DQ [=Fu Daolian], Qin L, Zhao Z, Zheng Y, Hosoya L-A, Chen $\mathrm{X}$, et al. Archaeobotanical Analysis at Tianluoshan: evidence for wild-food gathering, rice cultivation and the process of the evolution of morphologically domesticated rice. In: Center for the Study of Chinese Archaeology, Peking University, and Zhejiang Province Institute of Archaeology and Cultural Heritage, editors. Integrated Studies on the Natural Remains from Tianluoshan. Beijing: Wenwu Press; 2011a. pp. 47-96 (in Chinese).

Fuller DQ, van Etten J, Manning K, Castillo C, Kingwell-Banham E, Weisskopf A, et al. The contribution of rice agriculture and livestock pastoralism to prehistoric methane levels: an archaeological assessment. Holocene. 2011b;21:743-59.

Fuller DQ, Willcox G, Allaby R. Early agricultural pathways: moving outside the 'core area' hypothesis' in Southwest Asia. J Exp Bot. 2011c. doi:10.1093/jxb/err307.

Fuller DQ, Willcox G, Allaby R. Cultivation and domestication has multiple origins: arguments against the core area hypothesis for the origins of agriculture in the Near East. World Archaeol. 2011d;43(4):665-75. doi:10.1080/00438243.2011.624747.

Garris AJ Tai TH, Coburn J, Kresovich S, McCouch S. Genetic structure and diversity in Oryza sativa L. Genetics . 2005; 169 : $1631-1638$

Ge S, Sang T. Inappropriate model rejects independent domestication of indica and japonica rice. PNAS. 2011;108(39):E755. doi:10.1073/ pnas. 1111601108 .

Gorou P. Riz et civilisation. Paris: Fayard; 1984

Grillo MA, Li C, Fowlkes AM, Briggeman TM, Zhou A, Schemske DW, et al. Genetic architecture for the adaptive origin of annual wild rice, Orya nivara. Evolution. 2009;63-4:870-83.

Gross B, Olsen K. Genetic perspectives on crop domestication. Trends Plant Sci. 2010;15:529-37.

Guedes JA. Millets, rice, social complexity, and the spread of agriculture to the Chengdu Plain and Southwest China. Rice. 2011. doi:10.1007/s12284-011-9071-1.

Hardricourt AG. Domestication des animaux, culture des plantes et traitment d'autrui. L'Homme. 1962;2(1):40-50.

Harlan JR. Crops and ancient man. 2nd ed. Madison: American Society for Agronomy; 1975.

Harris DR. An evolutionary continuum of people-plant interaction. In: Harris DR, Hillman GC, editors. Foraging and farming: the evolution of plant exploitation. London: Routledge; 1989. p. 11-26.

Harvey EL. Early agricultural communities in Northern and Eastern India: an archaeobotanical investigation. Unpublished Ph.D. dissertation, University College London. 2006

Harvey EL, Fuller DQ, Mohanty RK, Mohanta B. Early agriculture in Orissa: some archaeobotanical results and field observations on the Neolithic. Man Environ. 2006;31(2):21-32.

He Z, Zhai W, Wen H, Tang T, Wang Y, Lu X, et al. Two evolutionary histories in the genome of rice: the roles of domestication genes. PLoS Genet. 2011;7(6):e1002100. doi:10.1371/journal.pgen.1002100.

Helbaek H. The paleoethnobotany of the Near East and Europe. In: Braidwood RJ, Howe B, editors. Prehistoric investigations in Iraqi Kuristan. Chicago: University of Chicago Press; 1960. p. 99-118.

Higham CFW. Languages and farming dispersals: Austroasiatic languages and rice cultivation. In: Renfrew C, Bellwood P, editors. Examining the farming/language dispersal hypothesis. Cambridge: McDonald Institute for Archaeological Research; 2003. p. 223-32.

Ho P-T. The indigenous origins of Chinese agriculture. In: Reed C, editor Origins of agriculture. The Hague: Mouton; 1977. p. 413-84.

Hosoya LA, Sato YI, Fuller DQ. Editorial: the archaeobotany of early rice agriculture in Asia. Archaeol Anthropol Sci. 2010;2:57-9.

Hunt HV, Campana MG, Lawes MC, Park Y-J, Bower MA, Howe CJ, et al. Genetic diversity and phylogeography of broomcorn millet (Panicum miliaceum L.) across Eurasia. Molec Ecol. 2011. doi:10.1111/j.1365-294X.2011.05318.x. 
Ishikawa R, Thanh PT, Nimura N, Htun TM, Yamasaki M, Ishii T. Allelic interaction at seed-shattering loci in the genetic backgrounds of wild and cultivated rice species. Gene Genet Syst. 2010;85:265-71.

Jiao T. Ancient environment and cultural changes in Southeast China during the Neolithic period. Antiquity. 2006;80:615-21.

Kawakami S, Ebana K, Nishikawa T, Sato Y, Vaughan DA, Kadowaki $\mathrm{K}$. Genetic variation in the chloroplast genomes suggest multiple domestication of cultivated Asian rice (Oryza sativa L.). Genome. 2007;50:180-7.

Kingwell-Banham E, Fuller DQ. Shifting cultivators in South Asia: expansion, marginalisation and specialisation over the long-term. Quat Int. 2011. doi:10.1016/j.quaint.2011.05.025.

Kumar A. Globalizing the prehistory of Japan: language, genes and civilization. London: Routledge; 2009.

Larson G., Liu R, Zhao X, Yuan J, Fuller DQ, Barton L, Dobney K, Fan Q, Gu Z, Liu X-H, Luo Y, Lv P, Andersson L, Li N. Patterns of East Asian pig domestication, migration and turnover revealed by modern and ancient DNA. Proc Natl Acad Sci USA.. 2010; 107(17): 7686-7691

Lee G-A. The transition from foraging to farming in prehistoric Korea. Curr Anthropol. 2011;52(S4):S307-29.

Liu X, Hunt H, Jones MK. River valleys and foothills: changing archaeological perceptions of North China's earliest farms. Antiquity. 2009;83:82-95.

Londo JP, Chiang Y, Hung K, Chiang T, Schaal BA. Phylogeography of Asian wild rice, Oryza rufipogon, reveals multiple independent domestications of cultivated rice, Oryza sativa. PNAS. 2006;103:9578-83.

Lu TL-D. Early pottery in South China. Asian Perspect. 2011;49 (1): $1-42$.

Madella M, Fuller DQ. Palaeoecology and the Harappan Civilisation of South Asia: a reconsideration. Quat Sci Rev. 2006;25:1283301.

McNally KL, Childs KL, Bohnert R, Davidson RM, Zhao K, Ulat VJ, Zeller G, Clark RM, Hoen DR, Bureau TE, Stokowski R, Ballinger DG, Frazer KA, Cox DR, Padhukasahasram B, Bustamante CD, Weigel D, Mackill DJ, Bruskiewich RM, Ratsch G, Buell CR, Leung H, Leach JE (2009) Genomewide SNP variation reveals relationships among landraces and modern varieties of rice. Proc Natl Acad Sci USA. 2009; 106 (30):12273-12278.

Meadow R. The origins and spread of agriculture and pastoralism in northwestern South Asia. In: Harris DR, editor. The origins and spread of agriculture and pastoralism in Eurasia. London: UCL Press; 1996. p. 390-412.

Molina J, Sikora M, Garud N, Flowers JM, Rubinstein S, Reynolds A, et al. Molecular evidence for a single evolutionary origin of domesticated rice. PNAS. 2011a;108:8351-6.

Molina J, Sikora M, Garud N, Flowers JM, Rubinstein S, Reynolds A, et al. Reply to Ge and Sang: a single origin of domesticated rice. PNAS. 2011b;108(39):E756. doi:10.1073/ pnas. 1112466108 .

Nasu H, Gu H, Momohara A, Yasuda Y. Land-use change for rice and foxtail millet cultivation in the Chengtoushan site, central China, reconstructed from weed seed assemblages. Archaeol Anthropol Sci. 2011. doi:10.1007/s12520-011-0077-9.

Nesbitt M, Simpson SJ, Svanberg I. History of rice in Western and Central Asia. In: Sharma SD, editor. Rice: origin, antiquity and history. Boca Raton: CRC Press; 2010. p. 308-40.

Nuijten E, van Treuren R, Struik PC, Mokuwa A, Okry F, Teeken B, et al. Evidence for the emergence of new rice types of interspecific hybrid origin in West African farmers' fields. PLoS One. 2009;4 (10): 7335 . doi:10.1371/journal.pone.0007335.

Pokharia A. Palaeoethnobotanical record of cultivated crops and associated weeds and wild taxa from Neolithic site, Tokwa, Uttar Pradesh, India. Curr Sci. 2008;94(2):248-55.
Qin L, Fuller DQ. Archaeobotanical evidence: Nanjiaokou site flotation report. In Henan provincial Institute of archaeology, editor. San Men Xia Nan Jiao Kou [Excavations of Nanjiaokou site]. Beijing: Science Press; 2009. P. 427-35.

Rolett BV, Zheng Z, Yue Y. Holocene sea-level change and the emergence of Neolithic seafaring in the Fuzhou Basin (Fujian, China). Quat Sci Rev. 2011;30:788-97.

Rowlands M. The unity of Africa. In: O'Connor D, Reid A, editors. Ancient Egypt in Africa. London: UCL Press; 2003. p. 39-54.

Ruddiman WF, Kutzbach JE, Varvus SJ. Can natural or anthropogenic explanations of late-Holocene $\mathrm{CO}_{2}$ and $\mathrm{CH}_{4}$ increases be falsified? Holocene. 2011;21:865-79.

Sagart L. The vocabulary of cereal cultivation and the phylogeny of East Asian languages. Bull Indo-Pac Prehist Assoc. 2003;23:127-36.

Sagart L. The expansion of Setaria farmers in East Asia: a linguistic and archaeological model. In: Sanchez-Mazas A, Blench R, Ross M, Lin M, Peiros I, editors. Human migrations in continental East Asia and Taiwan: matching archaeology, linguistics and genetics. London: Taylor \& Francis; 2008. p. 133-57.

Sang T, Ge S The puzzle of rice domestication. J Integr Plant Biol. 2007; 49(6):760-768 1195. change "provided by the author, summer 2011b" to: Comptes Rendus Palevol. 2011b; doi:10.1016/j. crpv.2011.07.004.

Saraswat KS. Plant economy of early farming communities. In: Singh BP, editor. Early farming communities of the Kaimur (excavations at Senuwar). Jaipur: Publication Scheme; 2004. p. $416-535$.

Saraswat KS. Agricultural background of the early farming communities in the Middle Ganga Plain. Pragdhara. 2005;15:145-77.

Sato, Y-I. DNA-ga Kataru Inasaku Bunmaei Kingento Tenkai (The origins of rice culture inferred from DNA analysis) (in Japanese). Tokyo: NHK Books; 1996.

Sergusheva EA, Vostretsov YE. The advance of agriculture in the coastal zone of East Asia. In: Fairbairn A, Weiss E, editors. From foragers to farmers: papers in honour of Gordon C. Hillman. Oxford: Oxbow Books; 2009. p. 205-19.

Song, J. The agricultural economy during Longshan period: an archaeobotanical perspective from Shandong and Shanxi. PhD Dissertation, University College London; 2011.

Southworth F. The linguistic archaeology of South Asia. London: Routledge; 2005.

Swedberg R. A note on civilizations and economies. Eur J Soc Theor. 2010;13:15-30

Sweeney MT, McCouch S. The complex history of the domestication of rice. Ann Bot. 2007;100:951-7.

Takahashi H, Sato Y, Nakamura I. Evolutionary analysis of two plastid DNA sequences in cultivated and wild species of Oryza. Breed Sci. 2008;233:225-33.

Tanaka K, Honda T, Ishikawa R. Rice archaeological remains and the possibility of DNA archaeology: examples from Yayoi and Heian periods of Northern Japan. Archaeol Anthropol Sci. 2010;2:69-78.

Trigger BG. Understanding early civilizations: a comparative study. Cambridge: Cambridge University Press; 2003.

Tsang C. Recent discoveries at a Tapenkeng culture site in Taiwan: implications for the problem of Austronesian origins. In: Sagart L, Blench R, Sanchez-Mazas A, editors. The peopling of East Asia: putting together archaeology, linguistics and genetics. London: Routledge-Curzon; 2005. p. 63-74.

Van Driem G. Rice and the Austroasiatic and Hmong-Mien homelands. In: Enfield N, White J, editors. Dynamics of human diversity. Canberra: Pacific Linguistics; 2011.

Van Driem G. The ethnologuistic identity of the domesticators of Asian rice. Comptes Rendus Palevol. 2011b; doi:10.1016/j.crpv.2011.07.004 
Vaughan DA, Lu B, Tomooka N. Was Asian rice (Oryza sativa) domesticated more than once? Rice. 2008;1:16-24.

Watsuji, T. Climate and culture: a philosophical study (translated from Fudo by G. Bownas). Westport: Greenwood; 1961.

Weber S, Lehman H, Barela T, Hawks S, Harriman D. Rice or millets: early farming strategies in central Thailand. Archaeol Anthropol Sci. 2010;2(2):79-88.

Wengrow D. What makes civilization? The ancient near East and the future of the West. Oxford: Oxford University Press; 2010.

Willcox G. The distribution, natural habitats and availability of wild cereals in relation to their domestication in the Near East: multiple events, multiple centres. Veg Hist Archaeobot. 2005;14:534-41.

Witzel M. Early sources for South Asian substrate languages. Mother Tongue Special Issue: 1-76; 1999.
Witzel M. Central Asian roots and acculturation in South Asia: linguistic and archaeological evidence from Western Central Asia, the Hindukush and northwestern South Asia for early Indo-Aryan language and religion. In: Osada T, editor. Linguistics, archaeology and the human past, vol. 2. Kyoto: Research Institute for Humanity and Nature; 2005. p. 87-211.

You X. The wild rice in Chinese ancient records (Zhongguo Gushu Zhong Jizai de Yeshengdao Tantao). Gujin Nongye [Ancient and Modern Agriculture]. 1987;1987(1):1-6. in Chinese.

Zhang C, Hung H-C. The Neolithic of Southern China: origin, development and dispersal. Asian Perspect. 2008;47(2):299-329.

Zhang C, Hung H-C. The emergence of agriculture in Southern China. Antiquity. 2010;84(323):11-25.

Zhao Z. New Archaeobotanic Data for the Study of the Origins of Agriculture in China. Current Anthropology 2011; 52(S4): S295-S306 